\title{
Порівняння практики розробки та впровадження клінічних настанов
}

\section{Вступ}

Узв'язку з набранням чинності увересні 2017 р. Угоди про асоціацію між Україною, з однієї сторони, та Європейським Союзом, Європейським співтовариством з атомної енергії та їхніми державами - членами, з іншої сторони (http://www.kmu.gov.ua/control/ uk/publish/article?art_id=248387631), особливої актуальності набувають питання реформування охорони здоров'я, зокрема удосконалення управління якістю медичної допомоги з урахуванням рекомендацій Ради Європи, а також можливості використання в Україні кращих прикладів із практики застосування сучасних механізмів методології клінічних настанов та стандартів медичної допомоги українах з більш успішними системами охорони здоров'я.

\section{Результати дослідження та їх обговорення}

Усі країни з сильними розвинутими економіками та різними формами організації медичної допомоги і способами фінансування, в тому числі й країни Європейського Союзу $(€ C)$, забезпечують розробку та впровадження клінічних настанов. Це також $є$ частиною міжнародного співробітництва, про що свідчать численні документи, такі як «Рекомендації щодо розробки настанов Ради Європи» (Council of Europe. Committee of ministers, 2001), фінансований ЄC проект AGREE (Burgers J.S. et al., 2004), Міжнародна мережа клінічних настанов (G-I-N), що координує діяльність національних органів з розробки клінічних настанов у світі тощо (Legido-Quigley H. et al., 2008). Проте практика розробки клінічних настанов у різних країнах різноманітна. Більшість країн мають схвалені програми з клінічних настанов і розробляють клінічні рекомендації з профілактики та/чи лікування захворювань. Деякі країни запровадили механізми забезпечення прозорості та наукової доведеності у процесі створення та використання клінічних настанов з метою забезпечення максимально можливої якості медичної допомоги, в той час як інші більш заінтересовані в розробці настанов і докладають узгоджених зусиль до створення систем їх використання.

Розробка клінічних настанов здійснюється на різних рівнях системи охорони здоров'я, у деяких випадках розробка координується на національному рівні, при цьому документи можуть бути адаптовані на регіональному та місцевому рівнях. Наприклад, в Англії клінічні рекомендації розробляють централізовано на базі Національного інституту охорони здоров'я та досконалості медичної допомоги (NICE), національних центрів співпраці та Королівських коледжів, але можуть бути адаптовані й запроваджені на місцевому рівні лікарнями, органами місцевого самоврядування, а також неурядовими організаціями. В Іспанії Програма клінічних настанов у рамках Національної системи охорони здоров'я координується Бібліотекою клінічних настанов для Національної системи охорони здоров'я, яка здійснює нагляд за розробкою клінічних настанов в агентствах з оцінки медичних технологій (ОМТ) різних автономних регіонів за участю експертів і професійних асоціацій. При цьому необхідно наголосити, що в процесі підготовки клінічних настанов обов'язково використовують спеціальні посібники з розробки клінічних настанов (Legido-Quigley et al., 2013).

Дослідження, проведене Європейською обсерваторією з систем та політики у сфері охорони здоров'я у 2013 р. (LegidoQuigley H. et al., 2013), розподіляє країни ЄС за ознаками національних процесів розробки клінічних настанов на три категорії. Перша категорія включає країни з давніми традиціями та широким досвідом у розробці та впровадженні настанов (Бельгія, Англія, Франція, Німеччина та Нідерланди). Друга категорія включає країни, які розпочали процес розробки та впровадження клінічних настанов (Люксембург, Угорщина, Латвія), але для більш обмеженого кола закладів та умов; і третя категорія включає ті країни, в яких виявлено лише перші кроки щодо використання настанов, і ті, в яких ініціативи в цій галузі все ще на стадії планування (Словенія, Греція).

У зазначеному дослідженні було виокремлено декілька сфер, за якими проводили аналіз практики розробки клінічних настанов, а саме: нормативно-правова база, органи, відповідальні за розробку настанов, заінтересовані сторони, контроль якості настанов та оцінка їх впливу. Роль юридичних повноважень для застосування настанов у різних країнах Європи різниться. Більшість країн не мають жодного правового забезпечення розробки клінічних настанов. Країни, в яких добре розвинені системи клінічних настанов, в основному запроваджують їх на добровільній основі.

Розробка клінічних настанов варіюється відповідно до того, які установи беруть на себе управління цим процесом і наскільки децентралізованим є цей процес. У більшості країн медичні асоціації беруть участь у розробці клінічних настанов, але їх вплив різної сили. У деяких країнах центральний орган/урядова чи незалежна організація несе відповідальність за координацію діяльності з розробки клінічних рекомендацій. Були визначені три основні групи країн: перша включає ті країни, в яких клінічні настанови розробляє уповноважена організація на загальнонаціональному рівні; у другій групі багато організацій долучаються до розробки клінічних настанов, але центральна організація координує таку розробку; і третя група включає країни, в яких професійні асоціації в основному відповідальні за розробку клінічних рекомендацій без координації з центру (табл. 1, 2).

Таблиця 1. Групування країн Європи за основним розробником клінічних настанов

\begin{tabular}{|c|c|c|}
\hline \multicolumn{3}{|c|}{ Країни, в яких } \\
\hline $\begin{array}{c}\text { клінічні настанови } \\
\text { розробляє } \\
\text { уповноважений } \\
\text { в центрі }\end{array}$ & $\begin{array}{c}\text { до розробки клінічних } \\
\text { настанов долучаються } \\
\text { багато організацій, } \\
\text { але центральний орган } \\
\text { координує процес }\end{array}$ & $\begin{array}{c}\text { професійні асоціації } \\
\text { в основному відповідальні } \\
\text { за розробку клінічних } \\
\text { рекомендацій }\end{array}$ \\
\hline $\begin{array}{l}\text { Англія, Фінляндія, } \\
\text { Люксембург }\end{array}$ & $\begin{array}{l}\text { Австрія, Кіпр, Чехія, Данія, } \\
\text { Естонія, Франція, } \\
\text { Німеччина, Угорщина, Італія, } \\
\text { Іспанія, Литва, Латвія, } \\
\text { Мальта, Норвегія, Румунія, } \\
\text { Швеція }\end{array}$ & $\begin{array}{l}\text { Бельгія, Болгарія, Греція, } \\
\text { Ірландія, Нідерланди, } \\
\text { Польща, Португалія, } \\
\text { Словаччина, Словенія, } \\
\text { Швейцарія }\end{array}$ \\
\hline
\end{tabular}

У країнах, що не мають власних розроблених клінічних настанов, приватні особи та організації керуються настановами, розробленими європейськими, американськими органами та органами з інших країн. Деякі установи, окрім розробки власних клінічних настанов, залучаються також на міжнародному рівні до мереж, створених для обміну знаннями, розвитку методології та координації медичної допомоги.

Участь усіх заінтересованих сторін $є$ ключовою особливістю у країнах з добре розвиненою системою розробки клінічних настанов і вважається важливою умовою для забезпечення прозорості. Залежно від контексту, до заінтересованих сторін входять представники професійних організацій, фармацевтичної промисловості, фінансових органів та постачальників послуг; пацієнти, їхні сім'ї, представники організацій хворих; науковці та інші спеціалісти, а також інші члени громадянського суспільства. Їх роль у розробці настанов різниться. У деяких країнах заінтер- 
Таблиця 2. Учасники розробки клінічних настанов у європейських країнах Урядові Неурядові установи

Країна

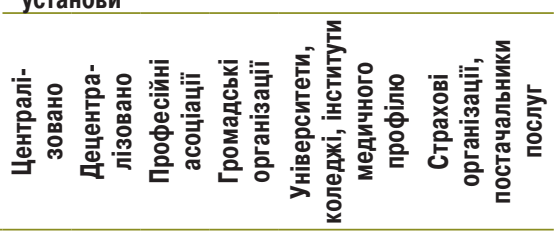

\begin{tabular}{|c|c|c|c|c|c|c|}
\hline Австрія & + & & + & + & + & + \\
\hline Бельгія & + & + & + & + & + & + \\
\hline Болгарія & + & & + & & + & \\
\hline Великобританія (Англія) & + & & + & & & + \\
\hline Греція & & & + & & & \\
\hline Данія & + & + & + & + & & \\
\hline Естонія & + & & + & & & + \\
\hline Ірландія & + & & & & & \\
\hline Іспанія & + & & + & + & & \\
\hline Італія & + & & + & & + & \\
\hline Кіпр & + & & & & & + \\
\hline Латвія & & + & + & & + & + \\
\hline Литва & + & & + & + & + & \\
\hline Люксембург & + & & + & & & + \\
\hline Мальта & & + & + & & & \\
\hline Нідерланди & + & & + & & + & \\
\hline Німеччина & + & + & + & & & \\
\hline Норвегія & + & & + & + & & \\
\hline Польща & & & + & & & + \\
\hline Португалія & + & + & + & & & \\
\hline Румунія & + & & + & & & \\
\hline Словаччина & + & + & + & & & \\
\hline Словенія & & & + & & & \\
\hline Угорщина & + & + & & & & \\
\hline Фінляндія & + & & + & & & \\
\hline Франція & + & & + & + & & \\
\hline Чеська Республіка & + & + & & & & \\
\hline Швейцарія & & & + & & & \\
\hline Швеція & + & + & + & & & \\
\hline
\end{tabular}

есованим сторонам пропонується використовувати свій вплив для сприяння запровадженню клінічних настанов на національному та місцевому рівнях. Проте пацієнти та їх організації зазвичай мало впливають на процес розробки клінічних настанов.

Організації, які приділяють особливу увагу якості настанов і прагнуть її визначити, в більшості випадків використовують загальновживаний Опитувальник з експертизи та оцінки настанов (AGREE), подекуди адаптований до місцевих умов, окремі організації розробили свої власні інструменти. Хоча деякі країни доклали значних зусиль, щоб оцінити клінічні рекомендації, проте більшість країн до 2010 р. не проводили будь-яку офіційну оцінку розробки, контролю якості, впровадження та використання настанов.

Загалом загальна концепція процесу розробки, впровадження та оцінки клінічних настанов представлена схематично на рисунку.
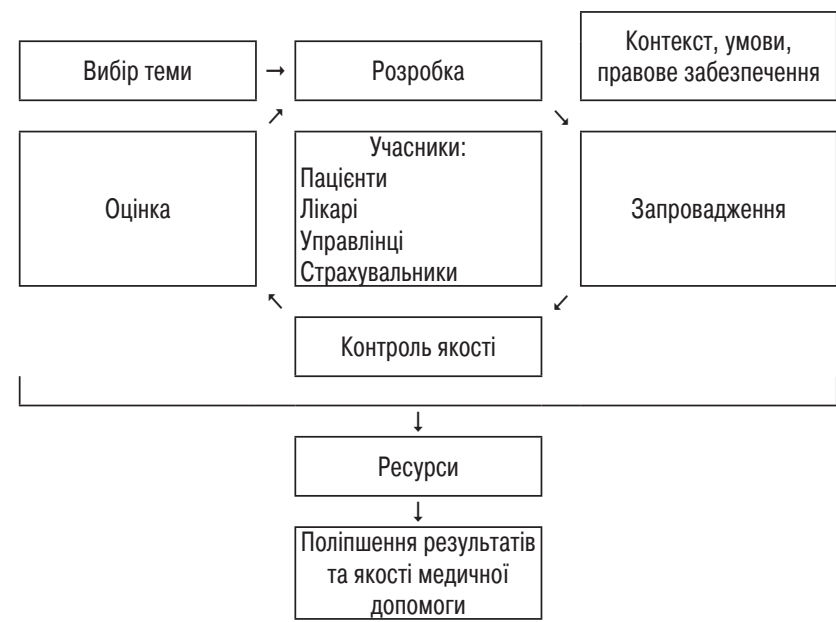

Рисунок. Концептуальна схема процесу розробки, впровадження та оцінки клінічних настанов (адаптовано з Council of Europe. Committee of ministers, 2001)
Наведемо детальнішу інформацію щодо деяких країн, досвід яких, на нашу думку, є корисним для удосконалення національної системи охорони здоров'я.

\section{Данія}

В Данії клінічні настанови розробляються для різних станів і особлива увага приділяється профілактиці та лікуванню хронічних неінфекційних захворювань. Дані стосовно інших інструментів, що допомагають медичним працівникам і пацієнтам у прийнятті відповідних рішень щодо хронічних хвороб, недоступні, хоча такі інструменти існують у системі охорони здоров'я Данії.

Закон про Охорону здоров'я визначає, що Національна рада з охорони здоров'я має право розробляти клінічні настанови. Проте на практиці професійні асоціації разом із місцевими органами влади також беруть участь у розробці.

Клінічні настанови розробляються як на центральному рівні, так і децентралізовано. Національна рада з питань охорони здоров'я, головний орган у сфері охорони здоров'я, через Секретаріат з національних клінічних настанов та інші свої підрозділи, а також Інститут раціональної фармакотерапії забезпечують розробку настанов на центральному рівні. Резюме настанов доступні англійською мовою. Регіональні та муніципальні органи влади, професійні організації та медичні товариства також розробляють клінічні настанови. Зокрема, Коледж лікарів загальної практики Данії (DSAM) розробляє власні настанови та бере участь у розробці на центральному рівні. Настанови доступні на спеціальному сайті (http://www.dsam.dk/).

В Данії не існує загальної методологічної рекомендації з підготовки, розробки та впровадження клінічних настанов.

Хоча очікується, що клінічні настанови загалом повинні відповідати міжнародним стандартам, немає формалізованих вимог щодо оцінки їх якості перед впровадженням. Якщо настанови використовуються для ОМТ, для оцінки якості настанов часто застосовують інструмент AGREE.

На сьогодні не існує жодного акта, який зобов'язує лікарів слідувати клінічним рекомендаціям, але на практиці лікарі повинні бути обізнаними і слідувати найкращій практиці, тобто клінічним настановам. Крім того, медиків часто підтримують різними ITпрограмами, в тому числі через Програми боротьби із захворюваннями. Дослідження, проведене В. Carlsen i P.K. Kjellberg (2010) показує, що лікарі загальної практики в Данії зіткнулися із труднощами доступу до настанов, пояснюючи низький рівень використання відсутністю єдиної платформи для пошуку доказових даних (Carlsen B., Kjellberg P.K., 2010).

Водночас розробка, контроль якості, впровадження та використання клінічних настанов оцінюються в рамках програм акредитації лікарень, що фінансуються державою.

\section{Франція}

У Франції клінічні настанови розроблені для більшості захворювань, насамперед хронічних станів. Такі настанови доступні на вебсайтах Французького національного органу охорони здоров'я (HAS) (http://www.has-sante.fr/) або Французького агентства з безпеки медичних засобів (AFSSAPS) - (http://ansm. sante.fr/).

HAS $€$ незалежним науковим державним органом, метою якого, серед іншого, є поширення належної практики в рамках французької системи охорони здоров'я. Клінічні настанови затверджені як частина результатів роботи HAS (Clerc I. et al., 2011) законом від 13 серпня 2004 р. № 2004-810 «Про медичне страхування», відповідно до якого розробляються та поширюються клінічні настанови та оцінюється іх впровадження.

У країні наявні три рівні розробки клінічних настанов: центральний під керівництвом HAS; регіональний під керівництвом регіональних органів влади для деяких станів; та під керівництвом окремих надавачів послуг у деяких випадках. HAS опублікував методику розробки клінічних настанов на своєму веб-сайті, яка полягає у розробці клінічних настанов двома методами: метод клінічних практичних настанов та метод формального консенсусу. Перший метод є більш поширеним та бажаним. Проте у разі відсутності доказових даних або суперечності між наявними даними може застосовуватися метод формального консенсусу. Згідно з першим методом група з розробки настанов (ГРН) складається з 15-20 фахівців з різних дисциплін, пов'язаних за темою, а також представників пацієнтів та/чи користувачів системи охорони 
здоров'я. Формулювання рекомендацій здійснюється на основ огляду літератури від імені ГРН. Після синтезу рекомендації рецензуються групою з 30-50 чоловік (зі складом, аналогічним до ГРН), за необхідності рекомендації уточнюються. Особливістю другого методу є те, що окрема група експертів (6-8 осіб) на основі критичного аналізу даних формують пропозиції для групи з оцінки, а потім після оцінки формують проект настанови. Група з оцінки (9-15 осіб) проводить два раунди голосувань щодо отриманих пропозицій. В кінці обидві групи доопрацьовують проект настанови (Haute Autorité De Santé, 2010).

HAS спрямований на максимальну прозорість та об'єктивність, забезпечуючи, аби групи з розробки й огляду були якомога більш незалежними, як в ролі редакторів, так і щодо конфлікту інтересів.

Комісія з настанов, а також Коледж HAS оцінюють рекомендації перед публікацією настанови на веб-сайті агентства. Система класифікації доказів на основі дизайну дослідження використовується в настановах як основа доказової бази кожної рекомендації.

Настанови HAS поширюються через веб-сайт агентства і також за допомогою допоміжних наукових публікацій і виступів на відповідних форумах. Рекомендації не є обов'язковими до виконання, від фінансових санкцій за недотримання незабаром після введення відмовилися. Спеціальне дослідження показало, що поінформованість лікарів не дуже висока і необхідне більш активне впровадження для досягнення вищого рівня застосування настанов (Clerc l. et al., 2011). Сімейні лікарі повинні слідувати так званим Оцінкам професійної практики, в ході яких їм повідомляють про настанови і просять порівняти їх практику з рекомендованою.

Методологія клінічних настанов HAS припускає, що агентство контролює розробку, щоб мати можливість ініціювати оновлення, якщо з'являються дослідження, що передбачають значне відхилення від існуючих рекомендацій. Враховуючи, що рекомендації не $є$ обов'язковими, ніякого офіційного механізму оцінки на сьогодні не існує.

\section{Німеччина}

У Німеччині клінічні настанови розробляються для різних станів, у тому числі для профілактики та лікування хронічних захворювань. Хронічні хвороби, зокрема, були об'єктом Програм з лікування захворювань, які реалізовувалися по всій країні фондами обов'язкового медичного страхування (для раку молочної залози і цукрового діабету 2-го типу з 2002 р.; ішемічної хвороби серця з 2003 р. та хронічної серцевої недостатності внаслідок ішемічної хвороби серця з 2009 р., для лікування астми та хронічного обструктивного захворювання легень (ХОЗЛ) - 22005 р.). Крім того, Інститут AQUA заохочує використання відповідних індикаторів якості від імені надавачів послуг. У листопаді 2017 р. база даних Асоціації наукових медичних товариств (AWMF) (http://www.awmf. org/) містила 964 клінічні настанови. Настанови також збираються Німецькою електронною бібліотекою охорони здоров'я, Arztbibliothek (http://www. arztbibliothek.de/).

AWMF, що об'єднує на сьогодні 175 медичних товариств та трьох асоційованих членів, координує розробку клінічних настанов від імені медичних асоціацій в Німеччині з 1962 р. У 2012 р. підготовлений посібник з розробки настанов, який також доступний англійською мовою. Окремий вид клінічних настанов - Національні настанови з лікування захворювань (NVL) формують основу для Програм з лікування захворювань і координуються AWMF i Німецькою лікарською асоціацією (ВӒК) у співпраці з Національною асоціацією лікарів обов'язкового медичного страхування (KBV) за допомогою іх спільного інституту Німецького агентства щодо забезпечення якості в медицині (AZQ). Ці установи погодили національні стандарти з розробки та впровадження рекомендацій на основі Рекомендацій Ради Європи $\operatorname{Rec}(2001) 13$ (Council of Europe. Committee of ministers, 2001). Використання клінічних настанов, заснованих на доказових даних, $€$ також невід'ємною складовою Статуту соціального забезпечення $\mathrm{V}$, який окреслює правила обов'язкового медичного страхування.

Розробка настанов у Німеччині відбувається як централізовано, так і децентралізовано. Централізовані настанови програми NVL включають настанови BÄK, KBV (AZQ) і AWMF, настанови Науково-консультативної ради ВӒК, а також Настанови з терапії Комісії з лікарських засобів ВӒК. Децентралізовані настанови, розроблені науковими медичними товариствами, координуються AWMF. Програма NVL має свою власну інструкцію з розробки на- станов, а AWMF i AZQ надають докладний посібник для децентралізованої розробки настанов.

Настанови, розроблені під керівництвом AZQ або AWMF, перевіряються на якість перед запровадженням у межах Arztbibliothek. Оцінка здійснюється за допомогою листа оцінки DELBI. DELBI заснований на інструменті AGREE I та адаптований до конкретних умов німецької системи охорони здоров'я. Оцінка здійснюється експертами з методології, які не були учасниками розробки настанови. AWMF класифікує настанови за методологічною основою, використовуючи так звану S-класифікацію: S1 - найнижча оцінка на основі думки експертів і S3 - найвища, що означає настанову, засновану на доказових даних і спеціальному консенсусі.

У Німеччині не існує чіткої юридичної вимоги щодо використання настанов. Проте факт того, чи дійсно лікування проводилося відповідно до офіційних настанов, може бути використаний як аргумент у ході розгляду випадків халатності (Fischer G., Berndt M., 2000). Фінансові стимули для запровадження настанов використовуються все частіше, особливо як частина контрактів за Програмами з лікування захворювань між установами соціального страхування та постачальниками медичних послуг. Інші наявні інструменти для впровадження рекомендацій включають Програми щодо індикаторів якості, такі як Програма для міжгалузевого забезпечення якості Федерального об'єднаного комітету в Інституті AQUA. Лікарні все частіше використовують IT-додатки із клінічними маршрутами на основі клінічних настанов. В установах, що надають амбулаторні послуги, ця розробка перебуває в зародковому стані.

Загальний національний порядок оцінки використання клінічних настанов відсутній. Національна академія сімейних лікарів регулярно оцінює всі рекомендації в межах свого напрямку. Розробка і якість клінічних настанов, координованих AWMF i AZQ, регулярно оцінюються цими організаціями. Впровадження та використання клінічних настанов оцінюється в рамках пакета контрактів з надання медичної допомоги і програм за допомогою індикаторів якості настанов. У 2004 р. Федеральний об'єднаний комітет доручив Інституту якості та ефективності охорони здоров'я (IQWiG) систематично досліджувати та оцінювати існуючі настанови (як німецькі, так і міжнародні) для того, щоб точно визначити необхідність оновлення положень, що лежать в основі Програм з лікування захворювань у Німеччині.

\section{Польща}

У Польщі існують клінічні настанови як для хронічних захворювань (наприклад ХОЗЛ, астма, гіпертонія і цукровий діабет), так і для гострих станів (наприклад емболія легеневої артерії та тромбоз глибоких вен). Національна фармацевтична політика на 20042008 рр. виявила необхідність розробки формулярів для медичної допомоги в амбулаторних умовах (receptariusz lecznictwa ambulatoryjnego), які б містили настанови з використання лікарських засобів у конкретних випадках і встановлені стандарти лікування з урахуванням їх вартості.

Національного стандарту чи правової основи для розробки клінічних настанов поки що не існує. Розробка клінічних настанов здійснюється децентралізовано. Враховуючи відсутність правової основи для розробки клінічних рекомендацій, у процес розробки можуть бути залучені різні установи, наприклад професійні організацій, фахівці, медичні товариства або Коледж сімейних лікарів Польщі (CFPiP) (https://www. klrwp.pl/pl). Процес не координується і ніяких вказівок зі стандартизації розробки клінічних настанов не виявлено.

Відсутні вимоги щодо оцінки якості клінічних настанов перед ї впровадженням. СоРFіР використовує підхід Дельфі для досягнення консенсусу серед експертів і залучених фахівцівпрактиків. Деякі існуючі клінічні настанови вже включають в себе індикатори якості, наприклад настанова з тромбозу глибоких вен або легеневої емболії.

Клінічні настанови необов'язкові в Польщі. Крім того, не виявлено жодних стимулів, щоб впроваджувати і використовувати схвалені настанови. Для сприяння застосуванню клінічних настанов лікарі загальної практики CoPFiP проводять семінари, лекції та видають публікації в «Lekarz Rodzinny».

Провідним польським видавцем спеціалізованої літератури і найбільшим польським центром медичної інформації для лікарів $€$ «Медицина Практична» (МП). Цей ресурс $€$ піонером і пропаган- 
дистом доказової медицини, медичної практики на основі надійних та найсучасніших публікацій, а також співзасновником Польського інституту доказової медицини. МП розробляє мультимедійні програми для лікарів (наприклад eMPendium, який об'єднує інформацію з найактуальніших публікацій МП), що доступні як для персональних комп'ютерів, так і для мобільних пристроїв. Веб-портал (www.mp.pl) € найбільш відвідуваним професійним медичним інтернет-сервісом у Польщі.

Оцінка клінічних настанов необов'язкова і здійснюється обмежено. CoPFiР частково контролює виконання клінічних настанов, і були ініційовані спорадичні науково-дослідницькі проекти з використання клінічних настанов.

\section{Румунія}

В Румунії існують клінічні настанови для різних станів, у тому числі для хронічних неінфекційних захворювань, зокрема таких, як цукровий діабет 2-го типу, незначний біль у попереку, депресія, астма і злоякісні новоутворення.

Розробка клінічних настанов є обов'язком Міністерства охорони здоров'я. Конкретні завдання делегуються експертним групам з різних клінічних спеціальностей, офіційно призначеним міністерством надавати консультації та рекомендації увідповідних сферах. Постанова Уряду (HG 351/2012) від 24 квітня 2012 р. змінила структуру Міністерства охорони здоров'я, аби включити Відділ оцінки медичних технологій (ОМТ). Серед інших завдань новий Відділ ОМТ відповідатиме за розробку методологічних настанов для проведення ОМТ і розробку клінічних настанов у тісній співпраці з іншими установами.

Клінічні настанови описані декількома юридичними документами: державні програми, акти Міністерства охорони здоров'я тощо.

Міністерство охорони здоров'я призначило 10 спеціальних комісій для різних напрямків медицини (таких, як Комісія з онкології тощо), які складаються з експертів та розробляють відповідні рекомендації. Це уповноважені зовнішні групи (квазі-урядов організації), які використовують не лише вказівки, наведені у наказах міністра з їх створення, а й існуючі міжнародні настанови з розробки рекомендацій. Особлива увага приділяється консенсусу. Для розробки клінічних настанов не існує чіткої методології.

Клінічні настанови, спрямовані на сімейних лікарів, також розробляються Національним центром сімейної медицини. Вони схвалені Національним товариством сімейної медицини і не пов'язані з актами уряду. Національний центр сімейної медицини випустив методологічний посібник з розробки клінічних настанов для власного використання. 3 методологією та настановами можна ознайомитися на веб-сайті (http://cnsmf.ro/).

Немає даних, що якість клінічних настанов оцінюється перед їх впровадженням. Тим не менш, інструмент AGREE використовувався для оцінки настанов перед їх фіналізацією, аби забезпечити дотримання належного процесу розробки.

Лікарі, як очікується, повинні запроваджувати клінічні рекомендації, розроблені Міністерством охорони здоров'я. Тим не менш, публікація клінічних настанов не пов'язана з конкретним процесом впровадження, і ніяких механізмів контролю для оцінки відповідності практики не існує. Клінічні настанови, розроблені Національним центром сімейної медицини, схвалені Національним товариством сімейної медицини, але вони не є обов'язковими. У той час як клінічні рекомендації доступні в інтернеті, не представлені зручні ІТ-додатки, спрямовані на полегшення їх використання.

Діють фінансові стимули на основі контракту постачальника послуг зі страховим фондом. Медичні заклади, які розробили та впровадили протоколи лікування, засновані на національних клінічних настановах, отримують додаткове фінансування. У той час як IT-додатки ще не набули поширення для підтримки впровадження клінічних настанов, для забезпечення поінформованості організовуються прес-конференції та публікації.

Відсутні дані щодо проведення оцінки після публікації клінічної настанови. Оскільки процес розробки клінічних настанов у Румунії все ще перебуває на ранній стадії, очікується, що відповідні механізми будуть розроблені в майбутньому.

\section{Бельгія}

В Бельгії існують клінічні рекомендації з профілактики та лікування хронічних станів.
Клінічні настанови, які використовуються в Бельгії, можна диференціювати як (i) неофіційні, розроблені на основі консенсусу (які розробляються групою експертів на основі їх думки і практичного досвіду), (iі) офіційні настанови, розроблені на основі консенсусу (з використанням систематичних методів), і (iіi) настанови, засновані на доказах. Останні розробляються групою клінічних експертів та експертів з методології, враховуючи докази, що базуються на відповідній літературі, практичному досвіді, цінностях, пріоритетах та інших обставинах.

Більшість клінічних настанов діють на місцевому, регіональному або національному рівнях. Різні організації беруть участь в розробці та впровадженні клінічних настанов. Деякі клінічні рекомендації - це локальні версії міжнародних клінічних настанов, тоді як в інших випадках поширюються міжнародні рекомендації без перегляду (наприклад рекомендації щодо артриту).

Незалежні асоціації розробили клінічні рекомендації для деяких хронічних станів. Бельгійська діабетична асоціація - неурядова асоціація за участю пацієнтів, практиків і викладачів - розробили клінічні рекомендації для цукрового діабету 2-го типу на основі Європейських рекомендацій. Бельгійське товариство кардіологів переглянуло міжнародні та Європейські рекомендації для розробки бельгійських рекомендацій з лікування ішемічної хвороби серця, Бельгійське товариство пульмонологів розробило клінічні рекомендації з лікування ХОЗЛ, що ґрунтувалися на даних Голландського товариства пульмонологів. Коледж онкології, пов'язаний з Центром експертизи знань (KCE) і спрямований на розширення використання доказової медицини, розробив і поширив клінічні рекомендації з лікування деяких видів раку. Також розроблені клінічні рекомендації для декількох інших хронічних станів.

Було створено декілька структур, що займаються поширенням використання клінічних настанов, таких як коледжі лікарів, КСЕ, Центр доказової медицини (CEBAM), EBMPracticeNet і Федеральна рада з якості сестринської справи. Однак в Бельгії відсутня центральна координація розробки клінічних настанов; при цьому їх розроблення може здійснюватися за ініціативою уряду та інших організацій.

На сайті СЕВАМ представлена покрокова інструкція з розробки клінічних настанов (http://www.cebam.be/nl/richtlijnen/ Paginas/Hoe-een-richtlijn-maken.aspx).

Розробка, поширення та оцінка клінічних настанов, що стосуються догляду за пацієнтами, більш систематично організовані та централізовані. Федеральна рада з якості сестринської справи, а також Федеральна державна служба (громадське здоров'я) і медсестри в бельгійських університетах вибирають, поширюють і впроваджують клінічні рекомендації щодо догляду за пацієнтами з хронічними захворюваннями. Настанови доступні трьома мовами (англійською, французькою та голландською). Ці рекомендації вибираються шляхом проведення огляду літератури та оцінки якості результатів.

Деякі організації (як централізовані, так і децентралізовані) , такі як університети, професійні асоціації, лікарні, наукові асоціації, медичні коледжі та неурядові організації, беруть участь у розробці та поширенні клінічних настанов.

Клінічні рекомендації можуть фінансуватися урядом або різними організаціями. Коли клінічні настанови фінансуються національними та регіональними органами влади, теми іноді вибираються цими органами, при цьому поважаючи професійну автономію розробників настанов.

32010 р. Національний інститут страхування здоров'я та інвалідності (NIHDI) підтримав розробку бази даних доказової інформації для фахівців охорони здоров'я: EBMPracticeNet (http:// www.ebp-guidelines. be/who). NIHDI у повному обсязі фінансує цей проект. Усі медичні працівники можуть безкоштовно користуватися EBMpracticeNet. Координація EBMPracticeNet покладена на СEВAM у співпраці з бельгійськими науковими дослідниками та Національною радою зі сприяння якості з метою створення бази зазначених настанов з належної практики.

В рамках централізовано структурованих організацій існує KCE (https://kce.fgov.be/fr/a-propos-de-nous), який було створено для просування доказової медицини шляхом оцінки практичних підходів, поширення ОМТ та рекомендацій. Крім того, Бельгійський комітет з координації політики щодо антибіотиків (ВАРСОС) 
відповідає за публікацію деяких клінічних рекомендацій. Наприклад, у програмі діяльності ВАРСОС на 2014-2019 рр. запланована розробка рекомендацій щодо амбулаторної антибактеріальної терапії для бельгійських медичних працівників.

Бельгія також $€$ членом G-I-N, незважаючи на наявність національних організацій. На сьогодні у G-I-N представлені три бельгійські організації: KCE, EBMPracticeNet та CEBAM. KCE співпрацює з Шотландською міжуніверситетською мережею з розробки клінічних настанов (SIGN) для підготовки оглядів літератури за конкретними ключовими питаннями.

3 початку 2000-х років процес розробки клінічних настанов став більш регламентованим. Одна з цілей EBMPracticeNet - це інтеграція інформації з бельгійських медичних організацій доказової медицини з інформацією, доступною в міжнародних документах, заснованих на доказах, включаючи їх адаптацію до місцевого контексту та поширення серед бельгійських фахівців у сфері охорони здоров'я.

Незважаючи на те що клінічні настанови стали більш засновані на доказах, методи розробки залишаються нестандартизованими на державному рівні. Зміст і структура різних клінічних настанов відрізняється у різних організацій. Зазвичай основними розробниками $є$ клініцисти, експерти щодо змісту й експерти з систематичного огляду. В урядових установах також можуть бути включені політики й економісти у сфері охорони здоров'я. До деяких рекомендацій також залучаються представники пацієнтів. Крім того, методологія розробки клінічних настанов, а також підхід до пошуку та оцінки практики доказової медицини варіюється в різних організаціях. Загалом критична оцінка доказів проводиться дослідниками або фахівцями охорони здоров'я з відповідним досвідом, набутим за допомогою спеціальної підготовки чи освіти. СЕВАМ забезпечує навчання з доказової медицини.

Валідація клінічних рекомендацій не обов'язкова, і для цього немає стандартних процедур. Організація, яка розробила клінічні рекомендації, відповідає за їх перевірку. Якщо є запит, CEBAM перевіряє клінічні настанови за допомогою інструменту AGREE в поєднанні з обмеженим аналізом змісту. Процедура перевірки приводить до рішення розробників рекомендувати чи не рекомендувати використовувати настанову. Іноді така перевірка $€$ необхідною умовою для отримання фінансування від уряду, наприклад для клінічних рекомендацій, запропонованих КСЕ.

Усі настанови щодо сестринської справи повинні оцінюватися на основі чотирьох критеріїв: AGREE, Cluzeau, Grilli i Shaneyfelt. Оцінки надаються університетами, а результати у вигляді загального балу за їх якість публікуються.

Поширення клінічних рекомендацій не стандартизоване. Організація, яка розробляє настанови, також несе відповідальність за їх публікацію. Бельгійські наукові асоціації та коледжі лікарів поширюють свої клінічні рекомендації через професійні джерела чи медичну місцеву пресу. Крім того, був запущений веб-сайт, який забезпечує доступ до широкого кола національних і міжнародних підходів до доказової медицини (https://www.cebam.be/ $\mathrm{nl} / \mathrm{cdlh}$ /paginas/default.aspx), a EBMPracticeNet також $є$ каналом для поширення клінічних настанов.

Клінічні рекомендації, адаптовані з інших країн або районів, зазвичай перевіряються щодо застосування в бельгійському контексті за допомогою інструменту ADAPTE, який використовується різними організаціями.

Використання рекомендацій не $є$ обов'язковим для лікарів, існує тільки юридична основа для впровадження клінічних рекомендацій в лікарнях з догляду за хворими. Однак доступ до деяких лікарських засобів, терапевтичні заходи або діагностичні втручання можуть підлягати вимозі відповідати клінічним настановам. Крім того, оцінка якості догляду за хворими ґрунтується на показниках, що містяться в настановах.

Впровадження клінічних рекомендацій не стандартизоване. Пропагуються багатогранні заходи і використовується безліч різних інструментів, включаючи протоколи догляду та клінічні маршрути пацієнтів. Новий інструмент, який повинен бути впроваджений - це система EBMeDS, яка надає фактичні дані за допомогою контекстуально залежної настанови в місці надання допомоги через електронний запис пацієнта.

На сьогодні немає офіційних даних про те, як в Бельгії використовуються клінічні рекомендації. Зазвичай їх використання не контролюється, крім окремих конкретних тем (таких як антибіотикотерапія).

Розробляється нова система оцінки клінічних рекомендацій щодо сестринського догляду. Деякі коледжі лікарів також визначають критерії оцінки клінічних рекомендацій і оцінюють їх, проте це не здійснюється систематично.

\section{Фінляндія}

Клінічні рекомендації розробляються Фінським медичним товариством Duodecim (https://www.duodecim.fi/), науковою асоціацією, яка працює над тим, щоб розвивати професійні навички лікарів і підтримувати їх клінічну практику подальшим навчанням, публікаціями та дослідними грантами.

Клінічні рекомендації не мають прямої правової бази. Однак в основному фінансуються фінськими урядом через Національний інститут охорони здоров'я та соціального забезпечення (THL), який $є$ урядовою організацією. Уряд також рішуче підтримує їх реалізацію.

Duodecim Medical Publications Ltd - компанія, що належить Фінському медичному товариству. Вона публікує інформаційні матеріали, призначені для медичних працівників як навчальний матеріал та на підтримку повсякденної діяльності.

Група Käурӓ hoito (Current Care Unit) готує загальнонаціональні рекомендації щодо догляду з метою поліпшення якості та зниження розбіжностей у практиці. Клінічні настанови призначені для підтримки лікарів в їх клінічній практиці та інтересів пацієнтів, що є основою для розробки клінічних маршрутів (Legido-Quigley H. et al., 2013).

На веб-сайті Current Care Unit представлено 106 національних клінічних рекомендацій (http://www.kaypahoito.fi/web/kh/ suositukset), багато з яких стосуються хронічних захворювань (таких як діабет, астма, ревматична хвороба та онкологія). Більшість клінічних рекомендацій зосереджено на профілактиці, та всі - на лікуванні. Клінічні рекомендації підтримують практичну роботу лікарів і становлять основу для складання програм допомоги на локальному рівні. Крім того, ці рекомендації застосовні до медичної практики в Фінляндії. Вони можуть також містити обґрунтовані коментарі з важливих питань охорони здоров'я, для яких немає наукових даних.

Current Care Unit та Duodecim є членами - засновниками G-I-N. Редакційна колегія Current Care очолюється радою, що складається з 15 членів, які представляють групу інтересів і групу управління Duodecim. Редакційний склад включає лікарів, які працюють неповний робочий час, або «Current Care editors», а також фахівців з інформації, технічних редакторів, які працюють над змістом, а також редакторів, які складають інформацію для пацієнтів та навчальні матеріали. Процес розробки клінічних настанов проводиться централізовано Duodecim. Внутрішня настанова з розробки клінічних рекомендацій створена і підтримувана Duodecim, ґрунтується переважно на методах і стандартах «GRADE» $i$ «AGREE».

Рада Current Care вибирає теми, які повинні бути охоплені клінічними рекомендаціями, переважно на основі пропозицій, зроблених спеціалізованими товариствами. Ці організації діють як приймаючі асоціації для відповідної настанови в партнерстві з Duodecim. «PRIO-інструмент» - набір критеріїв для оцінки пропозицій за орієнтовними темами - використовується для визначення пріоритетності нових тем. Систематичний огляд літератури за визначеною темою спочатку проводиться досвідченим спеціалістом з інформації. Далі робочі групи Current Care (включаючи висококваліфікованих фахівців в галузі охорони здоров'я з різних областей Фінляндії) розробляють засновані на доказах клінічні рекомендації у співпраці з редакторами Current Care, які працюють як експерти з методології. Перед завершенням настанова направляється у спеціальні групи за інтересами для критичного розгляду змісту і структури відповідно до критеріїв AGREE. Потім усі зауваження та коментарі обговорюються, і в разі потреби настанова коригується. За необхідності оголошується завершення роботи над клінічними рекомендаціями та подальші оновлення.

Використання клінічних настанов не обов'язкове, і немає ніяких фінансових стимулів, які заохочують їх використання. Вони не призначені для заміни оцінки лікарем або іншим медичним працівником з точки зору найкращої діагностики та лікування окремого пацієнта при прийнятті рішень під час надання медичної 
допомоги. Клінічні настанови широко використовуються на рівні первинної медико-санітарної допомоги у зв'язку з їх доступністю.

Використання клінічних настанов значно просувається через IT-додатки. Клінічні настанови інтегровані з системою EBMeDS, що дозволяє отримувати клінічні рекомендації з електронного запису пацієнтів. Процес, за допомогою якого створюється контент підтримки клінічних рішень EBMeDS, є першим у світі, який отримав акредитацію NHS.

Крім того, для підтримки впровадження клінічних настанов розроблені узагальнення, версії для пацієнтів, серії слайдів та онлайн-курси.

Донедавна оцінку клінічних рекомендацій не проводили регулярно. Однак із 2011 р. THL відповідає за контроль розробки, якості та використання клінічних рекомендацій.

\section{Чехія}

Клінічні настанови розробляються і періодично оновлюються в Чеській Республіці для таких хронічних станів: діабет, коронарна хвороба серця, астма, ХОЗЛ і рак. Крім того, було опубліковано понад 250 настанов різного ступеня складності з клінічної практики, починаючи з 2006 р. (вони періодично переглядаються та оновлюються) (Forýtková L., Bourek A. (Eds. ), 2008). Існує кілька веб-ресурсів для надання допомоги професіоналам і пацієнтам у прийнятті відповідних рішень щодо медичної допомоги хронічно хворим пацієнтам, але більшість цих ресурсів систематично не підтримується і не розвивається.

Із 2009 р. Національний довідковий центр (NRC) відповідає за розробку методології та впровадження Національної системи стандартів охорони здоров'я (NSHS) і Національного набору індикаторів послуг охорони здоров'я (NHSIS). Зараз здійснюється спільна розробка цих національних наборів стандартів для створення уніфікованих стандартизованих інструментів для підвищення якості медичної допомоги в чеській системі охорони здоров'я.

NRC є підрозділом Інституту післядипломної освіти та охорони здоров'я. Процес розробки клінічних настанов є централізованим; із 2007 р. NRC відповідає за розробку наборів національних клінічних настанов та індикаторів якості. Він тісно співпрацює та фінансується Міністерством охорони здоров'я, частково страховими компаніями і внесками Асоціації приватних лікарень. Наявна також децентралізована гілка, представлена видавничим домом DASHOFER, який фінансується за рахунок зовнішніх ресурсів і координується Центром якості охорони здоров'я медичного факультету Університету Масарика. Ці дві організації спільно працюють над розробкою клінічних настанов. При цьому методологія щодо розробки клінічних рекомендацій офіційно не визначена і не прийнята на національному рівні.

Інструмент AGREE широко використовується для контролю якості. Для основних стандартів контроль якості здійснюється професійними медичними асоціаціями (Чеська медична асоціація J.E. Purkyně).

Впровадження і використання клінічних рекомендацій не обов'язкове. Оцінка дотримання клінічних рекомендацій самоорганізовується. Клінічні рекомендації значно просуваються через IT-додатки та електронні бази даних, такі як Medi profi pro lékaře plus (https://www.mediprofi.cz/), SeniorZoneProfi (https://www. seniorzone.cz/).

Зараз розробляється методологія оцінки клінічних настанов.

\section{Угорщина}

В Угорщині наявні клінічні настанови з профілактики та лікування хронічних станів, а також інших захворювань. Клінічні рекомендації створюються кожним постачальником (лікарнею) індивідуально, але на основі централізованого адміністрування 32011 р. на центральному рівні виступають дві організації: Національна консультативна рада з охорони здоров'я (NABHC) і Haціональний інститут якості та організаційного розвитку в галузі охорони здоров'я та лікарських засобів (GYEMSZI).

Жоден конкретний акт чітко не регулює розробку та впровадження клінічних настанов. Однак План Семмельвейса, прийнятий у травні 2011 р., містить деякі положення щодо гарантій якості.

Угорська система клінічних настанов має як централізовані, так і децентралізовані компоненти: на їх основі NABHC надає настанови чи протоколи лікування. Потім постачальники (лікарні) відповідають за формулювання актуальних клінічних настанов для використання їх у власній установі. 3 березня 2011 р. NABHC контролює розробку і використання цих рекомендацій за кожним напрямком і визначає строк дії настанов (у нього є один відділ з кожної медичної галузі/спеціальності, який несе відповідальність також і за перегляд настанови).

Протоколи включають короткий вступ; дані про поширеність/ захворюваність для Угорщини за останні роки; а також інформацію про симптоми, профілактику, діагностику, обов'язкові й додаткові обстеження, адміністративну документацію, етапи та принципи лікування, реабілітації та ін.

NABHC відповідає за професійні стандарти. Професійні стандарти допомагають практикам у процесі прийняття рішень.

Контроль якості протоколів здійснюється GYEMSZI. Також використовується для забезпечення якості інструмент AGREE. На сьогодні GYEMSZI розробляє настанову з методології вдосконалення та уніфікації протоколів і клінічних настанов.

Після того, як були сформульовані клінічні рекомендації, вони $€$ обов'язковими в цьому медичному закладі.

Зараз існує партнерство між NABHC та GYEMSZI з метою встановити процеси оцінки у сфері впровадження клінічних настанов.

\section{Ірландія}

Ірландія не має повного комплекту клінічних рекомендацій, але використовує міжнародні рекомендації для багатьох медичних послуг. Проте зараз цей процес відбувається лише на спеціальній основі. Приклади конкретних настанов та стандартів включають ті, що стосуються симптоматичного лікування в мамології та внутрішньолікарняної інфекції. Ці рекомендації були затверджені через Орган інформації та якості у сфері охорони здоров'я (HIQA) (http://www.hiqa.ie), урядовий орган, який здійснює регулювання та перевірку послуг у галузі охорони здоров'я в Ірландії.

Служба охорони здоров'я Ірландії (HSE) впроваджує 30 програм на національному рівні, кожна з програм має директора з клінічних питань, спеціальним завданням якого є вдосконалення та стандартизація медичних послуг, та адміністративного менеджера. Є програми з діабету, інсульту, екстреної медицини, планової хірургії тощо. У рамках своїх функцій кожна програма забезпечить конкретний набір клінічних рекомендацій, узгоджених з медичним персоналом та забезпечить основу для нормалізації допомоги на національному рівні.

Національний комітет з клінічної ефективності (NCEC) був створений Департаментом здоров'я з метою (I) узгодження та затвердження загального підходу до розробки клінічних настанов у галузі охорони здоров'я на національному рівні; (II) погодження настанови та підходу до клінічного аудиту на національному рівні; і (III) досягнення підтримки від усіх заінтересованих сторін щодо обох вищезазначених пунктів. Комітет зараз схвалює модифікований інструмент AGREE II для оцінки клінічних настанов (з акцентом на загальні та хронічні захворювання).

Під оперативним крилом HSE реалізовується ряд програм з медичної допомоги, кожна з яких веде до принципових змін та вдосконалення в межах певних галузей, включаючи невідкладну медицину, серцеву недостатність, ХОЗЛ, астму, гострий коронарний синдром, діабет, внутрішньолікарняні інфекції, епілепсію, акушерство та гінекологію, а також екстрену хірургію. Фінансування здійснюється за окремими проектами, включаючи національні рекомендації. Участь у проектах окремих лікарень на сьогодні добровільна.

HIQA є законодавчим органом для вивчення невдач у наданні допомоги та припиненні надання послуг. Він звітує безпосередньо міністру охорони здоров'я. Роль HIQA полягає в розробці стандартів, перевірці та аналізі послуг у сфері охорони здоров'я та соціальної допомоги, а також підтримки обґрунтованих рішень щодо надання послуг. Громадська обізнаність, впевненість і довіра до «бренду HIQA» $€$ високими, і всі звіти HIQA публікуються, що зумовлює до високого рівня реагування в межах системи охорони здоров'я.

Програми медичної допомоги реалізуються паралельно з роботою NCEC. У поєднанні з регуляторною/дослідницькою роллю HIQA, множинність важелів позитивно впливає на систему охорони здоров'я в цілому. Крім того, в Ірландії (головним чином під егідою Національної програми боротьби з раком) ведеться процес 
раціоналізації центрів підтримки медичних послуг з централізованою допомогою в цих центрах; це має додаткову перевагу в тому, щоб забезпечити найкращу практику.

Національні програми очолює медичний персонал, який є дуже впливовим серед своїх колег та шанований на національному рівні. Кожна програма на сьогодні належним чином профінансована, навіть в умовах обмеженихпоточних економічних труднощів, і по суті є «єдиною грою в місті», тому узгодження пришвидшується.

Професійні компетентні програми стали обов'язковими для медичного персоналу з 2011 р. Усі лікарі повинні підписатися на систему страхування професійного коледжу, в результаті чого підвищується обізнаність щодо найкращої практики, а також стандартизація та прийняття клінічних рекомендацій.

У квітні 2015 р. HIQA разом з NCEC опублікували оновлену версію настанови щодо критеріїв якості для клінічних рекомендацій, щоб підтримати розробку високоякісних клінічних настанов, що включає інструмент AGREE II, адаптований спеціально до ірландського контексту (National Quality Assurance Criteria for Clinical Guidelines, 2015).

Клінічні рекомендації не обов'язкові, але ліцензування для організацій охорони здоров'я, імовірно, буде введено в майбутньому. Всі приватні медичні лікарні повинні бути акредитовані в міжнародному органі акредитації для того, щоб були доступними платежі.

Впровадження та використання клінічних рекомендацій оцінюються не регулярно.

\section{Англія та Уельс}

В Англії клінічні рекомендації застосовуються для лікування і профілактики різних захворювань як хронічних, так і інших (наприклад для профілактики інфаркту міокарда, ожиріння, зловживання алкоголю, цукровий діабет 2-го типу, серцево-судинні захворювання, розлади поведінки та психічні розлади). Клінічні рекомендації опубліковані й доступні на веб-сайті Національного інституту охорони здоров'я та досконалості медичної допомоги (NICE) (http://www.nice.org.uk).

NICE - незалежна організація, що фінансується Департаментом охорони здоров'я та відповідає за забезпечення національними настановами та встановленими стандартами якості з метою просування міцного здоров'я та профілактики і лікування захворювань. NICE випускає настанови для громадської охорони здоров'я, оцінки медичних технологій (препаратів, інтервенційних процедур, приладів та методів діагностики) та клінічні настанови, що містять рекомендації для закладів Національної медичної служби (NHS), місцевих органів влади та інших організацій у державному, приватному і громадському секторах стосовно нових та вже застосованих лікарських препаратів, методів лікування і процедур, а також щодо лікування та догляду за пацієнтами з конкретними захворюваннями і станами.

Усі рекомендації, стандарти та послуги розробляються NICE після консультування з незалежними комітетами і фахівцями які працюють у сфері охорони здоров'я, науковцями і представниками фармацевтичної промисловості, а також пацієнтами та представниками громадськості з належними знаннями чи інтересом у певній сфері. Національний центр співпраці при хронічних станах (NCCCC), який фінансується за рахунок NICE і діє на базі Королівського коледжу лікарів (RCP), відповідає за розробку клінічних настанов для лікування хронічних захворювань. Центр досконалості охорони громадського здоров'я розробляє рекомендації з послуг, які сприяють профілактиці хронічних захворювань, міцному здоров'ю і добробуту.

NICE був створений у 1999 р. для забезпечення рівного доступу до медичного лікування та високоякісної медичної допомоги від NHS по всій Англії та Уельсу. Департамент охорони здоров'я надає NICE повноваження розробляти клінічні настанови, настанови для громадської охорони здоров'я та оцінки технологій.

Медичні працівники повинні повною мірою враховувати клінічні настанови NICE при прийнятті клінічних рішень. Однак настанови не скасовують відповідальність медичних працівників за прийняття рішень з урахуванням обставин кожного пацієнта. Ці рішення повинні прийматися в консультації і за згодою пацієнта та/чи його опікуна чи піклувальника. Медичні працівники повинні документувати причини відхилення від положень клінічних настанов.
В Англії клінічні настанови розробляються централізовано NICE, Національними центрами співпраці (NCC) (за рахунок коштів NICE) і Королівськими коледжами, але можуть бути адаптовані та впроваджені на місцевому рівні через Госпітальні трасти NHS, Трасти первинної медичної допомоги, місцеві органи влади та громадські організації.

Якщо існують різні підходи, плутанина і невизначеність щодо лікарських засобів, пристроїв, лікування або інтервенційних процедур, Департамент охорони здоров'я і медичні заклади звертаються до настанов. Пріоритетність тем визначається на основі поширеності захворювання, впливу запропонованої настанови на ресурси, важливості у зв'язку з політикою уряду та рівня відмінностей у клінічній практиці.

Різні заінтересовані сторони - такі, як національні організації пацієнтів, медичні працівники, науковці, представники промисловості, постачальники послугі члени комісій - декларують свій інтерес і консультують розробників протягом усього процесу. NCC, якому доручено розробити настанову, визначає сферу і встановлює, що настанова буде охоплювати, а що ні. Створюється незалежна ГРН, її члени набираються через офіційні оголошення на вебсайті NICE шляхом подачі заяв та інтерв'ю. Члени групи повинні пройти формальне навчання з процесу розробки настанов.

Будь-який конфлікт інтересів має бути задекларований членами при подачі заявки на членство у групі й на початку кожного засідання у разі зміни статусу.

Група розглядає докази і формулює засновані на них висновки. У тому разі, якщо докази є слабкими або відсутні, для прийняття рішень застосовується процес неформального експертного консенсусу. У виняткових випадках, якщо при пошуку літератури не виявлено доказів щодо питання, яке розглядається, група може визначити належну практику, використовуючи формальні методи консенсусу за межами ГРН (наприклад метод Дельфі або метод номінальної групи).

Встановлюється принаймні один період громадського обговорення, що триває 8 тиж, протягом якого зареєстровані заінтересовані сторони можуть висловити свої зауваження щодо проекту настанови. У цей час NICE звертається до рецензентів із проханням провести статистичний та економічний огляд. ГРН аналізує всі отримані зауваження та вносить за необхідності зміни до настанови.

Незалежна група рецензентів перевіряє настанову, звертаючи особливу увагу на те, як ГРН опрацювала зауваження, отримані в ході громадського обговорення. Група також повинна переконатися, що підрозділи NHS зможуть реалізувати рекомендації. Виконавчий менеджер NICE затверджує остаточний варіант настанови, перш ніж він буде опублікований.

Настанови зазвичай підлягають оновленню через три роки після їх публікації, але часткові оновлення можуть бути проведені раніше, якщо з'являються нові докази.

Процес розробки клінічних настанов до січня 2015 р. засновувався на інструменті AGREE, що повною мірою описаний у Посібнику з розробки настанов 2009 р. (National Institute for Health and Clinical Excellence, 2009). У жовтні 2014 р. NICE опублікував оновлений посібник, в якому процеси і методи засновані на критеріях якості, що деталізовані в AGREE II, а також на первинних методологічних дослідженнях і оцінках, що проводяться командою NICE (National Institute for Health and Clinical Excellence, 2014).

Консультації із заінтересованими сторонами, рецензування експертами та оцінка незалежною групою є частиною процесу валідації. Перед публікацією настанова підлягає внутрішній оцінці якості в Центрі клінічної практики. «NHS Evidence» проводить свою оцінку настанови з тим, щоб користувачі могли віднайти джерела інформації найвищої якості, схвалюючи настанови печаткою у вигляді знака акредитації.

Настанови не проходять пілотного впровадження, але розробляються спільно з фахівцями-практиками та користувачами послуг. Як уже зазначалося, незалежна група з огляду настанови також відіграє важливу роль у забезпеченні того, що NHS зможе реалізувати остаточні рекомендації.

Остаточний тест на валідність настанов NICE відбувся під час судового розгляду в 2009 р. Позов проти NICE був поданий двома пацієнтами із синдромом хронічної втоми/міалгічним енцефаломієлітом. Підставами для позову були твердження про уперед- 
женість ГРН та її членів, що настанова була ірраціональною порівняно з доказами та про протиріччя стосовно класифікації стану і рекомендованого лікування. Верховний суд виніс рішення на користь NICE за всіма позовами, висунутими проти NICE.

Клінічні настанови носять рекомендаційний, а не обов'язковий характер, але повинні бути прийняті до уваги медичними працівниками при плануванні допомоги пацієнту. Всі організації NHS мають бути обізнаними стосовно стандартів NICE, аби гарантувати, що кожен пацієнт отримує однаково високоякісну допомогу.

NICE підтримує впровадження настанов шляхом залучення заінтересованих сторін, які можуть використовувати свої мережі і вплив для підтримки впровадження рекомендацій на національному та місцевому рівнях. Також NICE має команду консультантів із впровадження, які працюють на національному рівні для створення сприятливого оточуючого середовища, а також локально - для надання знань та підтримки навчання персоналу. На веб-сайті NICE доступні загальні інструменти реалізації, а також конкретні інструменти для кожної настанови, такі як шаблон оцінки вартості, який може бути використаний для оцінки місцевих витрат і заощаджень, пов'язаних із впровадженням; презентація, що висвітлює ключові пріоритети і забезпечує основу для місцевого обговорення; а також підтримка клінічного аудиту для моніторингу та оцінки місцевої практики (https://www.nice.org.uk/about/what-we-do/into-practice) Інші інструменти, які можуть бути отримані спільно із професійними та пацієнтськими організаціями, можуть включати поради щодо впровадження, щоб допомогти з плануванням дій на рівні закладів охорони здоров'я, шаблони листів-звернень, блок-схеми, інформаційні бюлетені та контрольні листи. NICE співпрацює з університетами і Королівськими коледжами, щоб допомогти майбутнім і нинішнім співробітникам NHS зрозуміти їх роль, і пропонує ряд ініціатив для підтримки майбутніх і нинішніх співробітників NHS в їх освіті та професійному розвитку.

Щороку NICE проводить Shared learning Awards, де практикуючі лікарі діляться своїми інноваційними й успішними підходами до впровадження рекомендацій NICE та стандартів.

Розробка стандартів якості NICE (які підтримують заклади NHS) стала важливим важелем у підтримці імплементації настанов. Наприклад, за допомогою нової концепції Департаменту запровадження якості та інновацій у сфері охорони здоров'я лікарня може втратити 0,3\% свого доходу, якщо не здійснить скринінг 90\% відповідних пацієнтів на тромбоз глибоких вен.

NICE випускає звіти з імплементації, які вимірюють запровадження конкретних положень, взятих з вибраних частин настанови на основі аналізу планових даних. Заінтересовані дослідники оцінюють запровадження та ефективність настанов для окремих випадків. Наприклад, стаття, опублікована в «British Medical Journal» (Thornhill M. et al., 2011), показала, що, незважаючи на зниження на 78,6\% призначення антибактеріальної профілактики після введення відповідної настанови NICE, дослідження не показало жодного значного підвищення захворюваності (або смерті) на інфекційний ендокардит протягом двох років. Звіти упорядковуються NICE в центральній базі даних.

\section{Сполучені Штати Америки}

У США наявні клінічні рекомендації для різних захворювань на федеральному рівні та в окремих штатах. Як частина федеральної Агенції з досліджень і якості в охороні здоров'я (AHRQ) функціонує Національний координаційний центр настанов - National Guideline Clearinghouse (NGC). На сайті NGC настанови доступні у вигляді резюме доказів для клінічної практики (https://www. guideline.gov/).

NGC розміщує клінічні настанови власне американського походження, а також багато документів з інших країн. Відбір для розміщення на сайті здійснюється за умови дотримання методології «Clinical Practice Guidelines We Can Trust», а також вимог до організацій-розробників. Між різними спеціалізованими організаціями, а також на локальному рівні здійснюється широкий обмін клінічними настановами, при цьому можливі незначні зміни текстута адаптація.

Водночас існує багато джерел клінічних настанов, які позиціонують себе як загальнонаціональні мережі, але рекомендації яких не беруться до уваги федеральними органами внаслідок методологічної невідповідності. Наприклад, NGC станом на кінець 2017 р. містить 440 клінічних настанов з онкології, половина з них (246 настанов) були розроблені безпосередньо в США, суттєва частка клінічних рекомендацій походила з Великобританії (16 настанов з British Society for Haematology Guidelines, 12 - National Guideline Alliance, 41 - NICE). При цьому не виявлено жодної клінічної настанови Американської національної загальної онкологічної мережі (NCCN), очевидно, що з методологічних міркувань: при ознайомленні з текстом таких настанов виявляється чимало експертних висновків, виявити підхід жорсткого відбору доказів не завжди вдається.

У США велика увага приділяється розкриттю конфлікту інтересів, проте його наявність, вчасно розкрита, не $є$ перепоною для участі в розробці або рецензуванні клінічних настанов.

Використання клінічних настанов заохочується професійними організаціями, які можуть дублювати такі клінічні настанови через власні джерела, а також на місцях - для закладів, які беруть участь у федеральних програмах фінансування медичної допомоги Medicare, Medicaid. Крім того, стандарти акредитації закладів охорони здоров'я побудовані на клінічних настановах, які доступні на сайті NGC

Велика увага приділяється практичному застосуванню доказових клінічних рекомендацій. Типовий план впровадження клінічної настанови від AHRQ містить такі позиції:

1. Визначення конкретних ролей і обов'язків співробітників, лідера та членів команди впровадження.

2. Визначення організації роботи, шляхи постійного зв'язку та звітності, розробка механізмів підзвітності.

3. Визначення стратегії впровадження нової практики.

4. Удосконалення попереднього плану впровадження.

5. Забезпечення підтримки ключових заінтересованих сторін.

6. Початок пілотної перевірки нових методів.

7. Створення стратегії залучення персоналу.

8. Розроблення навчальних планів з метою допомогти співробітникам опанувати нову практику.

Порівняння процесів клінічних настанов на прикладі відповідних органів Англії та США наведені в табл. 3.

\section{Висновки}

Клінічні настанови на сьогодні розглядаються серед інструментів досягнення кращої практики у сфері охорони здоров'я, спрямовані на поліпшення здоров'я населення шляхом оптимізації медичної допомоги, зосереджені на засобах досягнення її удосконалення, заснованих на доказах. Більшість країн запровадили клінічні настанови з початку 1990-х років, що потребувало значних ресурсів для їх розробки та запровадження.

Одна з важливих функцій клінічних настанов полягає в узагальненні знань. Враховуючи обсяг клінічних досліджень, опублікованих по всьому світу, потреба в засобах, які б узагальнювали цю інформацію, очевидна. Практикуючі лікарі, які бажають надавати своїм пацієнтам максимально якісну допомогу, при цьому проводячи більше часу з ними, повинні мати легкий і повний доступ до наукової інформації з клінічних питань, враховуючи, що адекватність допомоги, яку отримують пацієнти, значною мірою залежить від того, як добре поінформований лікар. Проте для того, щоб клінічні настанови відповідали очікуванням і просували найкращу практику при одночасному покращенні взаємної довіри та взаємодії між пацієнтом та лікарем, вони повинні бути хорошої якості й належним чином поширюватися.

у більш розвинених системах охорони здоров'я клінічні настанови зосереджені головним чином на діагностиці та лікуванні конкретних станів та їх ускладнень. Проте комплексний підхід більш ефективний не лише для забезпечення найкращого догляду, але й з фінансової точки зору: поєднання рекомендацій щодо запобігання, діагностики та лікування (тобто загальних настанов з громадського здоров'я) може сприяти більш ефективним втручанням і загальному поліпшенню здоров'я.

Застосування клінічних настанов є добровільним та завжди безпосередньо в тексті документа можна знайти акценти на тому, що клінічна настанова не є замінником професійної відповідальності та клінічного мислення медичного працівника, ніколи не містить вичерпного переліку рекомендованих втручань або виключає застосування будь-яких інших, не зазначених в ній, способів надання медичної допомоги. У результаті аналізу матеріалів з методології клінічних настанов на доказових засадах не виявлено даних стосовно прямої дії клінічних настанов як законодавчого акту в жодній із країн. 
Таблиця 3. Порівняння процесів клінічних настанов і національних стандартів в США та Англії

Країна/параметри Джерело інформації

Agency for Healthcare Research and Quality (AHRQ) - Агенція

з досліджень та якості в охороні здоров'я

National Guideline Clearinghouse (NGC) - Національний координаційний центр Настанов (https://www.guideline.gov/) виконавчої влади Установа, відповідальна за клінічні настанови Методологія розробки настанови (http://www.ahrq.gov/)

Центральний орган U.S. Department of Health \& Human Services (HHS, Департамент США з охорони здоров'я та соціальних служб)

\section{Федеральна агенція}

AHRQ 3 Національним координаційним центром настанов NGC Методологія визнана та оприлюднена на сайті NGC (https://www.guideline.gov/help-and-about/summaries/ inclusion-criteria)

Clinical Practice Guidelines We Can Trust. Institute of Medicine Committee on Standards for Developing Trustworthy Clinical Practice Guidelines (2011) (https://www.ncbi.nlm.nih.gov/books/NBK209538/)

Клінічні настанови - це твердження, що включають рекомендаці спрямовані на оптимізацію медичної допомоги пацієнтам, та формуються шляхом систематичного аналізу доказів і оцінки переваг і шкоди альтернативних варіантів медичної допомоги. Клінічні настанови втілюють і підтримують взаємозв'язки між ключовими учасниками процесу прийняття клінічних рішень. Замість того, щоб диктувати підхід щодо допомоги пацієнтам 3 єдиним універсальним шаблоном, клінічні настанови можуть посилити прийняття рішень клініцистом і пацієнтом, чітко описуючи та оцінюючи наукові докази й аргументи (ймовірні користь і ризик) за клінічними рекомендаціями, роблячи їх релевантними до індивідуальних потреб пацієнтів
Aнгілія

(https://www.england.nhs.uk/)

The National Institute for Health and Care Excellence (NICE) - Національний інститут охорони здоров'я та досконалості медичної допомоги (https://www.nice.org.uk/)

U.K. Department of Health (Департамент здоров'я), відповідальний також за соціальну допомогу Державний орган NICE

Методологія визнана та оприлюднена на сайті NICE:

Developing NICE guidelines: the manual (oct.2014) (https://www.nice.org. uk/process/pmg20/chapter/introduction-and-overview)

US) Quality standards Process guide (may, 2016) (https://www.nice.org.uk/Media/Default/Standards-and-indicators/ Quality-standards/quality-standards-process-guide-jul-16.pdf)

, Рекомендації в цій настанові представляють точку зору NICE, яка сформувалася після ретельного розгляду наявних доказів. При прийнятті рішень фахівці повинні враховувати цю настанову поряд з індивідуальними потребами, уподобаннями і цінностями своїх пацієнтів або користувачів послуг. Застосування рекомендацій цієї настанови не обов'язкове, настанова не скасовує відповідальності медичних працівників за прийняття рішень, відповідно до потреб конкретного пацієнта, при консультуванні пацієнта і/або їх опікуна.

Місцеві уповноважені особи і/або постачальники послуг несуть відповідальність за те, щоб ця настанова застосовувалася, коли окремі фахівці в галузі охорони здоров'я та їх пацієнти чи користувачі послуг мали бажання ї̈ використовувати. Вони повинні робити це в контексті місцевих і національних пріоритетів для фінансування та розвитку служб і з урахуванням їх обов'язків, належним чином враховувати необхідність ліквідації незаконної дискримінації, заохочувати рівність можливостей і зменшувати нерівність щодо здоров'я. Ніщо в цій настанові не повинно тлумачитися таким чином, щоб це не відповідало дотриманню цих обов'язків NICE погоджує тему для розробки з Департаментом зі здоров'я та соціальної допомоги та NHS, розробники визначаються за конкурсом

Рекомендовані до виконання, застосовуються у суді

NICE надає статус до виконання після схвалення NHS

Не обов'язкові до виконання, використовуються для планування та підтримки найкращого рівня якості медичних послуг, в тому числі урядовими органами

та розробників клінічних $\quad A H R Q$ визначив перелік установ та організацій - можливих настанов

Статус клінічних настанов Наявність національних державних/федеральних стандартів

Впровадження

національних стандартів

Наявні стандарти акредитації.

Спеціальні - діють у рамках федеральних програм Medicare Medicaid

Clinical Practice Guidelines We Can Trust. Institute of Medicine (US) Committee on Standards for Developing Trustworthy Clinical Practice Guidelines:

Стратегії імплементації, які стосуються процесу інтеграції основного змісту клінічних настанов у контекст і процес місцевої практики, включають клінічні нагадування, короткі довідники та засоби підтримки прийняття рішень.

Протоколи підтримки прийняття клінічних рішень (CDS) повинні задовольнити потреби кінцевих користувачів, призначення відповідного персоналу, а також точки включення в клінічний процес
Стандарти якості NICE представляють собою набір конкретних, коротких заяв і пов'язаних із ними вимірів. Базуються на клінічних настановах, які, у свою чергу, базуються на фактичних даних (доказах). Встановлюють бажані, але досяжні, маркери високої якості, економічно ефективної допомоги. Спрямовані на поліпшення структури, процесу і результатів медичної допомоги.

Встановлення рівнів досяжності відбувається на місцевому рівні

\section{Список використаної літератури}

Agree Research Trust (2001) The appraisal of guidelines for research \& evaluation (AGREE) instrument (http://www.agreetrust.org/resourcecentre/).

Burgers J.S., Fervers B., Haugh M. et al. (2004) International assessment of the quality of clinical practice guidelines in oncology using the Appraisal of Guidelines and Research and Evaluation Instrument. J. Clin. Oncol., 22(10): 2000-2007.

Carlsen B., Kjellberg P.K. (2010) Guidelines; from foe to friend? Comparative interviews with GPs in Norway and Denmark. BMC Health Serv. Res. 10: 17.

Clerc I., Ventelou B., Guerville M.A. et al. (2011) General practitioners and clinical practice guidelines: a reexamination. Med. Care Res. Rev., 68(4): 504-518.

Council of Europe. Committee of ministers (2001) Recommendation $\operatorname{Rec}(2001) 13$ of the Committee of Ministers to member states on developing a methodology for drawing up guidelines on best medical practices (http://mtd.dec. gov.ua/images/doc/Rec(2001)13.pdf).

Fischer G.C., Berndt M. (2000) Medizinische Leitlinien: Juristische Dimension. Dtsch. Arztebl., 97(28-29): https://www.aerzteblatt.de/archiv/23672/ Medizinische-Leitlinien-Juristische-Dimension.

Forýtková L., Bourek A. (Eds.) (2008) Programy kvality a standardy lečebnych postupů, Editorstvi Standardů lečebnych postupů (Programmes of quality and standards of medical procedures). Dashofer Verlag, Prague.
Graham R., Mancher M., Miller Wolman D. et al. (Eds.) (2011) Clinical Practice Guidelines We Can Trust (https://www.ncbi.nlm.nih.gov/books/ NBK209539/).

Haute Autorité de Santé (2010) Practice guidelines: «Formal consensus» method (https://www.has-sante.fr/).

Legido-Quigley H., McKee M., Nolte E., Glinos I.A.; World Health Organization, Regional Office for Europe European Observatory on Health Systems and Policies (2008) Assuring the quality of health care in the European Union: a case for action (http://apps.who.int/iris/bitstream/10665/107894/1/E91397.pdf).

Legido-Quigley H., Panteli D., Car J. (2013) Clinical Guidelines for Chronic Conditions in the European Union (http://www.euro.who.int/_data/assets/pdf file/0009/195876/Clinical-Guidelines-for-Chronic-Conditions-in-the-EuropeanUnion.pdf).

National Institute for Health and Clinical Excellence (2009) The guidelines manual. London.

National Institute for Health and Clinical Excellence (2014) Developing NICE guidelines: the manual. London.

National Quality Assurance Criteria for Clinical Guidelines (2015) Health Information and Quality Authority and National Clinical Effectiveness Committee (http://health.gov.ie/wp-content/uploads/2015/07/HIQA-NCEC-National-QualityAssurance-Criteria-NCG-v2-April-2015.pdf).

Thornhill M.H., Dayer M.J., Forde J.M. et al. (2011) Impact of the NICE guideline recommending cessation of antibiotic prophylaxis for prevention of infective endocarditis: before and after study. BMJ, 342: d2392.

Одержано 26.12.2017 